\title{
The Relationship Between Teacher's Profession and Teachers' Teaching Ability on (Field Experience Program) PPL's Students of State University of Medan (Unimed) College Year 2005/2006
}

\author{
Nur'aini \\ State University of Medan (Unimed), Indonesia \\ nuraini_as59@yahoo.com
}

\begin{abstract}
This study aims to look at the relationship between perception of the teacher profession and prospective teacher' teaching ability on (Field Experience Program) PPL's Students of State University of Medan. Teacher's profession according to community's perspective is still considered not too important. The community / parents of students sometimes ridicule and accuse the teacher of being incompetent, not qualified and so on. When their son / daughter cannot solve the problem that they face or they have no ability they want. The sample in this study are Unimed's Student in $7^{\text {th }}$ Semester as many as 96 people who have taken the Field Experience Program (PPL) using purposive sampling. The method of collecting data in this study are documentation and questionnaires. The documentation method is used to find out data about teaching abilities, GPA values, and macro values. While the questionnaire method of perception of the teaching profession is based on several indicators which are the core of the teacher's code of ethics as professional staff. The findings shows that there is a very significance positive of the relationship between perception of the teacher profession and prospective teacher' teaching ability on (Field Experience Program) PPL's Students and the index of student cumulative achievement with the ability of Unimed's student, Freg $=19,845$ with $p<0,000$. This means that the more positive the perception of the teaching profession and the higher the student's GPA, the better the ability to teach.
\end{abstract}

Keywords: perception; teacher profession; teaching ability

\section{Introduction}

Teacher's profession at this time is still widely talked about by people, or is still questionable by people, both among educational experts and outside education experts. Mass media, especially print media, both daily and weekly, contains news about teachers. Ironically, the news tends to harass the position of the teacher, both of which involve public interests to things that are very personal in nature, while on the teacher's side they are barely able to defend themselves. The community / parents of students sometimes ridicule and accuse the teacher of being incompetent, not qualified and so on, when their son / daughter cannot solve the problem that they faces himself or they have no the ability that they want. The attitude and behavior of community is indeed not without reason, because there are indeed a small number of individual teachers who violate / deviate from their code of ethics. Strangely enough, even the slightest mistake made by the teacher invites a reaction that is so great in society. This is understandable because the existence of such an attitude shows that the teacher should be a role model for the surrounding community. More than just an example, this also shows that the teacher is still considered to exist, because until any time the teacher's position will not be replaced even with a sophisticated machine because the teacher's duty involves fostering human mental characteristics involving unique human aspects the noodles are different from each other. The problem is limited to what the public 
acknowledges the teaching profession, because in reality the community still recognizes the profession of doctor or judge is considered higher than the teacher profession.

\subsection{Teaching Ability}

\section{Theory of Literature}

Rooijakkers (in Sagala, 2003) teaching means conveying or transmitting knowledge and views. In this case both students and instructors must understand the material to be discussed, in other words in the teaching activity there must be a learning process. Dare that between teaching and learning there is a significant correlation where teaching is an input from education Providing skills and knowledge to students which is a teaching process (teaching and learning process) is carried out by teachers in schools using certain methods or methods. This is the method of teaching (Suryosubroto, 1997). Teaching methods can also be interpreted as ways of implementing rather than teaching processes or about how technically a lesson material is given to 'students at school. Meanwhile teaching according to Yasaratodo (2004) is that an activity (process) teaches students. This activity cannot be carried out by just anyone. Only those who have gained experience and training through education and training taken in a relatively long time to the university level are eligible to be allowed to carry out learning activities in educational institutions.

Teacher's teaching ability or competence refers to the ability to carry out something obtained through education. Competence refers to perfomen and rational actions, to fulfill certain verifications in the implementation of straightforward education. It is said to be rational because it has direction and purpose, while performance is real behavior in the sense that it can not only be observed, but also covers more distant from the unseen. Teacher's teaching ability is one of the things that must be possessed in any level of education because that ability has its own interests and is very important for the teacher to have because teacher's teaching ability is a selection tool in receiving prospective teachers. With the conditions as the acceptance criteria for prospective teachers, there will be guidelines for administrators in choosing teachers needed for one school.

\subsection{Perception of Teacher Professionals}

Walgito (1991) says that perceptions come from English, namely perception, which means capture or sight. In addition, Chaplin (1990) suggested that perception is knowing or observing objective objects and events with the help of the senses. Meanwhile Gibson (1991) suggests that perception is a process of giving meaning to the environment by individuals. Rachmat (1996) says that perception is an observation of objects, events and relationships obtained by gathering information in interpreting messages. Most behaviors and individual adjustments are determined by their perceptions. My behavior and individual attitude towards the object depends on the individual's response to the object through his perception. Walgito (1991) outlines the factors that influence the formation of perceptions divided into two factors, namely stimulus factors or the environment (external) and internal factors. Both of these factors interact with each other in the individual. While the individual circumstances that can influence their perceptions are two sources, namely those related to physical (physiological) and those related to psychological aspects. Etymologically, the term profession comes from the English "profession" which is rooted in Latin "profeus" which means "to recognize" or "declare capable or expert in one form of work". In semantics the profession is a position or job that demands expertise (expertise) from its members. That is, 
the work cannot be done by any person who is not trained or not specifically prepared to do the work (Samsuri: 1991).

\section{Research Methods}

This study identifies variables namely independent variables that discuss perceptions of the teaching profession, dependent variables that discuss teaching ability, participation variables that discuss the Grade Point Average (GPA), moderator variables that discuss gender, and control variables that discuss the value of macro teaching. The sample in this study were 96 semester Unimed students using purposive sampling which was based on the characteristics of students who had characteristics such as Regular Unimed Students, Following the 2006/2006 odd semester PPL, were in semester 7 and NIM 2002. The method of collecting data in this study is the method of documentation and questionnaires. The documentation method is used to find out data about teaching abilities, GPA values, and macro values. While the questionnaire method of perception of the teaching profession is based on several indicators which are the core of the teacher's code of ethics as professional staff.

\section{Discussion}

The purpose of the distribution normality test is to prove that the spread of research data that is the center of attention has spread based on the principle of normal curves. Distribution normality test was analyzed by using the chi square formula. Based on the analysis, it is known that the perception variable on the teaching profession, GPA and the ability to teach, follows a normal distribution, which is distributed according to the principle of the normal Ebbing Gauss curve. As a criterion if $p>0.050$ then the distribution is declared normal, on the contrary if $\mathrm{p}<0.050$ the distribution is declared abnormal (Hadi and Pamandingsih, 2000). The following table is a summary of the results of the distribution normalization test.

Table 1: Summary of Calculation Result of Distribution Normality Test

\begin{tabular}{|c|c|c|c|c|c|}
\hline Variable & Average & $\mathrm{CHI}^{2}$ & SB & $\mathrm{p}$ & Information \\
\hline $\begin{array}{c}\text { Perception of the teaching } \\
\text { profession }\end{array}$ & 164,127 & 7,592 & 15,693 & 0,370 & Normal \\
\hline source of variation & 2,827 & 8,458 & 0,240 & 0,076 & Normal \\
\hline Teaching ability & 74,527 & 4,081 & 5,763 & 0,906 & Normal \\
\hline
\end{tabular}

$\mathrm{CHI}^{2}=$ Price of Kai Squares

$\mathrm{SB}=$ Standard Deviasi

$\mathrm{P} \quad=$ Opportunity for error

The research results obtained from this study, namely there is a very significant positive relationship between the perceptions of the teaching profession and the student cumulative achievement index with the ability to teach UNIMED Medan students, Freg = 19,845 with $\mathrm{p}<0,000$. This means that the more relationship between perception of the teacher profession and prospective teacher' teaching ability on (Field Experience Program) 
PPL's Students of State University of Medan., the better the ability to teach. The results of this regression analysis can be seen in the following table.

Table 2: The results of this regression analysis

\begin{tabular}{|l|l|l|l|l|l|l|}
\hline $\begin{array}{l}\text { Source of } \\
\text { Variation }\end{array}$ & $\mathrm{JK}$ & $\mathrm{db}$ & $\mathrm{RK}$ & $\mathrm{F}$ & $\mathrm{R}^{2}$ & $\mathrm{p}$ \\
\hline full regression & 776,458 & 2 & 388,229 & 19,845 & 0,433 & 0,000 \\
\hline $\begin{array}{l}\text { residual } \\
\text { regression }\end{array}$ & $1.017,292$ & 52 & 19,563 & $==$ & $==$ & $==$ \\
\hline Total & $1.793,750$ & 54 & $==$ & $==$ & $==$ & $==$ \\
\hline
\end{tabular}

Information :

JK : Total of squares

$\mathrm{Db} \quad$ : Degree of freedom

RK : Average of squares

$\mathrm{F} \quad$ : Regression coefficient

$\mathrm{R}^{2} \quad$ : Determinant coefficient

$\mathrm{P} \quad$ : Opportunity for error

$\mathrm{F} \quad$ : Koefisien regresi

R2 : Koefisien delerrninan

$\mathrm{P} \quad$ : Opportunity for error

The results of this study illustrate that there is a very significant positive relationship between the perception of the teaching profession and the student grade point average with the ability to teach UNIMED Medan students, Freg $=19,845$ with $p<0,000$. The more positive perceptions of the teaching profession and the higher the student's GPA, the better the ability to teach. Conversely the more negative perceptions of teacher performance and the lower the student's GPA, the teaching ability will also get worse. Based on the results of this study, it can be stated that the responses and judgments given by a student to the teaching profession will determine how they are capable of teaching. A professional teacher based on having a positive perception of the teaching profession will be able to manage the class as expected. The teacher's ability can be optimal if it is based on having a positive perception of the teaching profession by having a positive perception of the profession being undertaken, so the teacher or prospective teacher will be fully aware of various tasks.

\section{Conclusion}

Based on the results obtained in this study, it can be concluded that there is a very significant positive relationship between perceptions of the teaching profession and the student grade point average with the ability to teach UNIMED Medan students, Freg = 19,845 with $\mathrm{p}<0,000$. This means that the more positive the perception of the teaching profession and the higher the student's GPA, the better the ability to teach. On the contrary, the more negative perceptions of the teaching profession and the lower the student's GPA, the better the teaching ability will be. There is a very significant positive relationship between the perception of the teaching profession and the teaching ability of UNIMED Medan students, by controlling the influence of and the student cumulative achievement index, where $\mathrm{r} 1, \mathrm{y}-2=$ $0.452 ; \mathrm{p}<0.010$. Based on these results, it can be stated that the more positive the students 'perceptions of the teaching profession, the more it increases students' teaching abilities 


\section{References}

Gibson, J. L., Ivaniscvich, J. M. dan Donelly, Jr. J. H. I983. Organisasi, Perilaku, Srruktur dan Proses. Jakana : ErIangga.

Hadi, S. 1986. Metodologi Research I. Yogyakarta : Andi Offset.

LPTK. 2004. Profesi Kergndidikan. Medan : Universitas Negcri Medan.

Rakhmad, .I. I996. Psikoloui Komunikasi. Edisi Revisi. Cetakan Kedclapan. Bandung 1 PT. Remaja Rosdakarya.

------I989. Metode Penelilian Komunikasi. (dilengkapi dengan contoh analisis statislik). Edisi Kedua. Bandung: Remaja Rosda Karya.

Rooijakkers, I99 I. Mcnggjar dengan Sukses, Jakarta : Grasindo

SagaIa, S. 2003. Konseg dan Makna Pembelajaran. Bandung : Alfabeta

Singarimbun, M dan Effendi, OU. I99I. Mctode Pcnelitian Survey. Surabaya : Bina IImu.

Sudjana, N. I988. Penelitian dan Penilaian Pendidikan. Bandung 1 Sinar Batu.

Suryosubrolo, B. 1997. Proses Bclajar Mengaiar Di Sekolah, Jakana : Rincka Cipta

Sutisna, O. I985. Administrasi Pendidikan. Dasar Teoritis untuk Praktck Profesional. Bandung: Angkasa.

Thoha, M 1993. Psikologj Kgmunikasi. Bandung: Rosdakarya.

Uzer, U. 1997. Meniadi Guru Profesional. Bandung. Remaja Rosdakaxya.

Walgito, B. 1991. Psikologi Sosial. Suatu Pcngantar. Yogyakana : Andi Offset.

Wijaya, G dan Rusyan, T. I991. Kemampuan dasar Duru Dalam Proses Being Mengajar. Bandung. Remaja Rosdakarya.

Yasaratodo, 2004. Kemamguan Dasar Mcngajar. Medan. Fakultas llmu Pendidikan Universitas Negeri Medan. 